\begin{tabular}{|l|l|l|l|l|}
\hline \multirow{2}{*}{ aptara } & CUAN & cuan12022 & Dispatch: May 30, 2013 & CE: N/A \\
\cline { 2 - 5 } & Journal & MSP No. & No. of pages: 3 & PE: Sarah \\
\hline
\end{tabular}

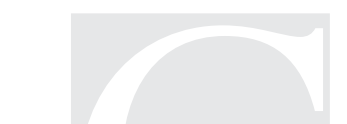

\title{
THE CLOSET, ITS CONVENTIONS, AND ANTI-RACIST CRITICISM
}

\author{
ROBYN WIEGMAN \\ Duke University
}

There have been many things said in the popular press about Steven Spielberg's sensationalist rendition of American history in his award winning film Lincoln (2012), but as far as I know no one has accused him - yet — of being just a bit too interested in Thaddeus Stevens's bedroom. If you saw the film, you no doubt remember that the last time we see Senator Stêvens, played by Tommy Lee Jones, he is in his nightgown, giving his mistress, Lydia Hamilton Smith, the signed $13^{\text {th }}$ Amendment. In the landscape of U.S. national fantasy, the black woman as housekeeper-slash-mistress functions here, as Erica Edwards has brilliantly argued, as the suture of national unity; it is literally in her hands - and indeed across her supine body - that the nation and its future are symbolically secured (2013). While the scene is rich in annoyance, what provokes me today is its particular reliance on the narrative language of the closet, as Spielberg positions the viewer inside the house with Smith, played by S. Epatha Merkerson, when Stevens enters and hands over his cane and wig. Seconds later, employer and employee are in bed. In psychoanalytic terms, they have taken up residence in the space of the dream, which means that interracial sex not only plays the role of national secret but animates the film's own wish to convert the modern world-making trauma of slavery and violence into a domestic tale of interracial love.

I raise the specter of U.S. national fantasy for two primary reasons. First, I want to make sure that the specific interdisciplinary domain of American Studies is present in our discussions today in its long-standing commitment to an anti-racist

CULTURAL ANTHROPOLOGY, Vol. 28, Issue 3, pp. 543-545. ISSN 0886-7356, online ISSN 1548-1360. (C) 2013 by the American Anthropological Association. All rights reserved. DOI: 10.1111 /cuan.12022 
2 historiography of race, which is meaningful not only for those of us trained as

3 Americanists but for all of us who teach in the U.S. university where, arguably, 4 every field practices, whether consciously or not, American Studies. And, second, 5 I want to introduce a hermeneutic - psychoanalysis - that has been both vexing 6 and vital to the critical itinerary of race across a number of fields. Vexing, not 7 only because of the bourgeois Viennese contexts in which Freud developed his 8 most compelling understandings of psychic life in the industrial west, but vexing 9 as well because of the institutionalized comportment of psychoanalysis in the U.S. 10 where psychologism and its tenants of ego realism took hold in mid-century to render 11 personhood in individualist terms, making the subject, as metonym for American 12 culture, both stable and whole.

13 In our present context, this psychologism underlies the discourse of the post-racial, which equates an agential, self-knowing racialized subject with an introjection so historically profound it can only be taken as the resolution of national disorder. This is the psychic double bind that a black president represents to the U.S. national imaginary, which not only requires the performance of racial injury in order to repeatedly deny it, but must compulsively deny it in order to remember that the injury was real. This structure - and indeed I think of it as a structure - of knowing and not knowing has its richest cultural valence in the figure of the closet, a concept that Eve Kosofsky Sedgwick developed in epistemological, not merely metaphoric terms, for understanding the political conditions in which asymmetries of power attach to relations of speech and silence, visibility and invisibility, and knowledge and ignorance (1990).

If Spielberg casts interracial sex as the deep secret of national life- thanks no doubt to Tony Kushner's not-at-all-queer screenplay - the language of the closet that represents it is not, as it were, misbegotten. Indeed, interracial sex is routinely caught in the closet's revolving door, brought out in the light of day, sometimes with the help of DNA, only to be quarantined again because the power it wields is the power it wields as "the" national secret. What, then, does this mean for American Studies scholars who write their commitment - our commitment - to anti-racist historiography by staging our critical act as an intervention into the closet's closeting conventions? While we are bound to read the scenes differently from Spielberg, indeed radically so, don't we share the belief that political truth is on the side of opening the closet door, exposing the ignorance it protects in the hope, which is always shattered, that our interpretation will hold? In psychoanalytic terms, our interpretative repetition is crucial to the epistemology of the closet, 
Stoler once called "racism's contemporary anti-racist historiography"- which I interpret as the anti-racist historiography framed by contemporary racism itself (1997: 184). My contribution to this discussion lies here, in asking us to consider the critic's relation to the epistemology of the closet as it conditions not only the remembered and disavowed histories of racism, but the ongoing work of anti-racist criticism.

\section{REFERENCES CITED}

Edwards, Erica

2013 Plenary Address: the Female Without; or, on the Limits of the Black Political. In Thinking Feminism at the Limits. Columbia University. Sedgwick, Eve Kosofsky

1990 Epistemology of the Closet. Berkeley: University of California Press. Stoler, Anne

1997 Racial Histories and their Regimes of Truth. Political Power and Social History.

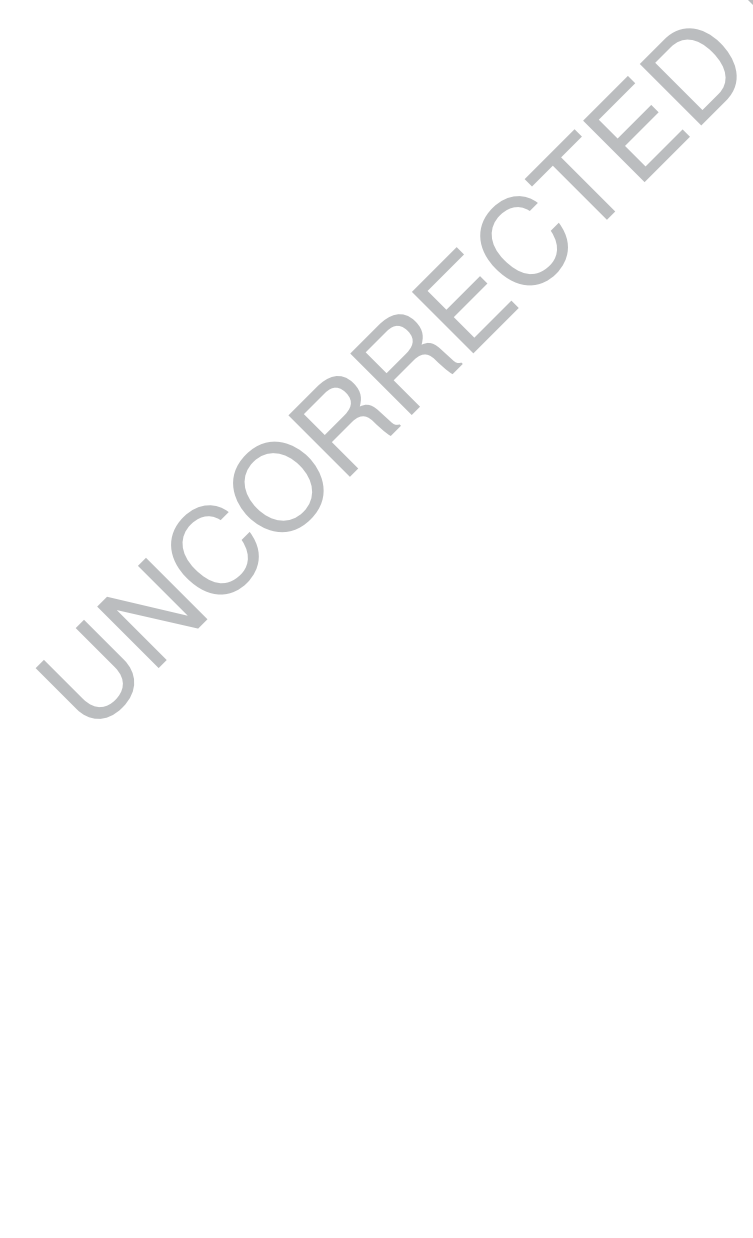

